\title{
River Sources of Dissolved Inorganic Carbon in the Gulf of Trieste (N Adriatic): Stable Carbon Isotope Evidence
}

\author{
Samo Tamše • Nives Ogrinc • Lynn M. Walter • \\ Daniela Turk • Jadran Faganeli
}

Received: 7 September 2013 / Revised: 28 March 2014 / Accepted: 2 April 2014

(C) Coastal and Estuarine Research Federation 2014

\begin{abstract}
River inputs can significantly affect carbon dynamics in the costal ocean. Here, we investigate the influence of four rivers (Isonzo/Soča, Timavo/Reka, Rižana, and Dragonja) on inorganic carbon (C) in the Gulf of Trieste in the northern Adriatic Sea using stable isotope signatures of dissolved inorganic carbon $\left(\delta^{13} \mathrm{C}_{\text {DIC }}\right)$. In 2007 , rivers exported $1.03 \times 10^{11} \mathrm{~g} \mathrm{C}$ in the form of dissolved inorganic carbon (DIC) to the Gulf of Trieste with the lowest export observed in the Dragonja and the highest in the Isonzo/Soča. River plumes were associated with higher total alkalinity (TA) and $p \mathrm{CO}_{2}$ values compared with Gulf of Trieste waters, but their inputs showed high spatial variability. The $\delta^{13} \mathrm{C}_{\text {DIC }}$ values and the isotopic mass balance suggested that river input during the spring of 2007 represented about $16 \%$ of DIC at our study site
\end{abstract}

\footnotetext{
Communicated by Alberto Vieira Borges

S. Tamše $\cdot N$. Ogrinc $(\triangle)$

Department of Environmental Sciences, Jožef Stefan Institute,

Jamova 39, 1000 Ljubljana, Slovenia

e-mail: nives.ogrinc@ijs.si

S. Tamše $\cdot$ N. Ogrinc

Jožef Stefan International Postgraduate School, Jamova 39, 1000 Ljubljana, Slovenia

L. M. Walter

Department of Geological Sciences, University of Michigan, 1018 C.

C. Little Building, Ann Arbor, MI 48109-1063, USA

D. Turk

Department of Oceanography, Dalhousie University, Halifax, Nova

Scotia, Canada

D. Turk

Lamont-Doherty Earth Observatory, Earth Institute at Columbia

University, Palisades, NY, USA

J. Faganeli

Marine Biological Station, National Institute of Biology, Fornače 41, 6330 Piran, Slovenia
}

Published online: 18 April 2014
VIDA, located in the southeastern part of the Gulf of Trieste. During autumn of 2007, the riverine contribution of DIC was less pronounced ( $3 \%$ ) although the river export of $\mathrm{C}$ was higher relative to the spring season. Convective mixing with the Gulf of Trieste waters and bora wind events appear to reduce the riverine contribution to the DIC system. Our results suggest that river plumes play an important role in $\mathrm{C}$ cycling in the Gulf of Trieste by direct inputs of higher riverine DIC and by increased biological uptake of DIC promoted by the supply of riverine nutrients.

Keywords Rivers · Carbonate system - Stable carbon isotopes $\cdot$ Coastal region

\section{Introduction}

The coastal ocean is biogeochemically one of the most active areas in the biosphere due to terrestrial nutrient input. As it represents only about $7 \%$ of the total ocean area (Borges 2005; Borges et al. 2005), the $\mathrm{CO}_{2}$ system has only recently been explicitly considered in global carbon $(\mathrm{C})$ budgets. The input, production, and degradation rates of organic matter in coastal waters are frequently much higher compared with the open ocean, suggesting that $\mathrm{CO}_{2}$ fluxes could potentially be significant. Coastal water environments include marginal seas, which are thought to be $\mathrm{CO}_{2}$ sinks (e.g., Chen and Borges 2009) and estuaries, which appear to be $\mathrm{CO}_{2}$ sources due to high organic matter input and very high degradation rates, i.e., a heterotrophic system (e.g., Borges et al. 2006). Recent emission of $\mathrm{CO}_{2}$ to the atmosphere from estuaries was estimated to be $0.27 \pm 0.23 \mathrm{Pg} \mathrm{C}$ year $^{-1}$, while the sink of atmospheric $\mathrm{CO}_{2}$ over continental shelf areas was calculated to be $-0.21 \pm 0.36 \mathrm{Pg} \mathrm{C}$ year $^{-1}$ (Laruelle et al. 2010). The global natural transport from rivers to the ocean was estimated to be about $0.8 \mathrm{Pg} \mathrm{C}$ year $^{-1}$, half of which is organic and half 
inorganic (Meybeck 1982, 1993; Sarmiento and Sundquist 1992) with the additional flux of about $0.1 \mathrm{Pg} \mathrm{C}_{\text {year }}{ }^{-1}$ (mainly organic C) derived from human activity (Meybeck 1993). Recent estimates indicated that the coastal ocean currently receives $\sim 0.96 \mathrm{Pg} \mathrm{C}$ year $^{-1}$ (inorganic and organic) from terrestrial sources (Andersson et al. 2005).

The mean molar proportions of dissolved inorganic (DIC), dissolved organic (DOC), and particulate organic carbon (POC) carried by global rivers was found to be $45: 37: 18$ (Meybeck 1993) and is distinct from the mean proportions for world rivers draining carbonate areas such as Yangtze River (DIC/DOC/POC=71:4:11; Wu et al. 2007), Rhone River (DIC/DOC/POC=82:6:8; Sempere et al. 2000), and Sava River (DIC/DOC/POC=89:9:2; Ogrinc et al. 2008). The total annual river discharge of DOC is about $2.1 \times$ $10^{12}$ mol year $^{-1}$, and most of it is exported to the Atlantic Ocean (Opsahl et al. 1999 and references therein). Much of the organic $\mathrm{C}$ is deposited and/or degraded and outgassed close to land, mostly within estuaries (Smith and Hollibaugh 1993). The outgassing of anthropogenic C from estuaries can also represent a significant term in comparison with regional $\mathrm{CO}_{2}$ emission estimates (e.g., 5 to $10 \%$ for Western Europe; Frankignoulle et al. 1998). The natural DIC transport via rivers, however, is part of a large-scale cycling of $\mathrm{C}$ between the open ocean and land associated with the dissolution and precipitation of carbonate minerals. This natural cycle drives net outgassing from the ocean on the order $0.6 \mathrm{Pg} \mathrm{C}_{\mathrm{Cear}}{ }^{-1}$ globally.

On a global scale, an important negative feedback between continental weathering and global average surface temperature () entails the consumption of $\mathrm{CO}_{2}$ through dissolution of silicate minerals and transport of DIC to the oceans (Berner and Berner 1996). Riverine C fluxes to the oceans that are controlled by processes occurring within a rivers' drainage basin largely regulate ocean water chemistry. Carbonate dissolution and precipitation play an important role in the transformation of terrestrial C. Calcite saturation indices for waters discharging from major world river systems are nearly all at or below equilibrium (Kempe 1982; Salisbury et al. 2008). Investigations of streams draining carbonate-bearing watersheds have observed a decrease in alkalinity at low and high discharge conditions (Grosbois et al. 2000; Szramek et al. 2007), but only few studies have characterized the riverine carbonate dynamics in small watersheds. As perturbations to the global $\mathrm{C}$ cycle increase, the riverine flux to the oceans may drastically change local conditions as watersheds adjust to the new climatic conditions. Watershed changes will likely be the most evident in the smaller streams. Considering the great reactivity and solubility of carbonates (Amiotte Suchet et al. 2003), the C flux from carbonate dissolution to surface and ground waters increases with enhanced water flux and soil zone $p \mathrm{CO}_{2}$. This in turn increases the flux of riverine inorganic $\mathrm{C}$ to the sea where most $\mathrm{CO}_{2}$ is ultimately isolated from the active C pool by carbonate precipitation (Szramek et al. 2007; Kanduč et al. 2008).

Over the last few decades, the data on inorganic and organic constituents was complemented by isotope tracers, including stable $\mathrm{C}$ isotopes, however only a few studies have been devoted to the use of $\mathrm{C}$ isotopes to trace different DIC sources to follow the riverine DIC transport into the ocean (Yang et al. 1996; Telmer and Veizer 1999; Aucour et al. 1999; Hellíngs et al. 1999; Hélie et al. 2002; Brunet et al. 2005). Stable isotope composition of dissolved inorganic carbon $\left(\delta^{13} C_{\text {DIC }}\right)$ of fresh water ranges from -25 to $0 \%$. Dissolution of carbonates produces a solution with an intermediate $\delta^{13} \mathrm{C}_{\text {DIC }}$ of about $-11 \%$. In the Amazon River, DIC originates mainly from decomposition of organic matter with low $\delta^{13} \mathrm{C}_{\text {DIC }}$ of $-28 \%$, (Longinelli and Edmond 1983), whereas in the St. Lawrence River system, DIC originates from dissolution of carbonates and equilibration with the atmosphere (Yang et al. 1996). The Rhine represents the mixture of both (Aucour et al. 1999). In river systems progressive ${ }^{13} \mathrm{C}$ enrichment is commonly observed along the river drainage path due to isotopic exchange with the atmospheric $\mathrm{CO}_{2}$ and in situ photosynthetic activity (Telmer and Veizer 1999). In the surface ocean, atmospheric exchange results in a ${ }^{13} \mathrm{C}$-enrichment towards an equilibrium $\delta^{13} \mathrm{C}_{\text {DIC }}$ ranging from -1 to $2.2 \%$ (Kroopnick 1974) over the world with the least variations at equatorial regions and greater variability at higher latitudes. Seasonal trends are controlled by several processes; photosynthesis and respiration by organisms, atmospheric exchange, decomposition of organic matter, solution of carbonates, and the surface and groundwater base runoffs. During photosynthesis, organisms preferentially take up ${ }^{12} \mathrm{C}$, leading to an increase in $\delta^{13} \mathrm{C}_{\mathrm{DIC}}$, whereas during decomposition of organic matter, isotopically light carbon $\left({ }^{12} \mathrm{C}\right)$ is released, thereby decreasing $\delta^{13} \mathrm{C}_{\text {DIC }}$ values.

The Gulf of Trieste is a small and shallow marine basin in the northern part of the Adriatic Sea. The Gulf exhibits complex hydrodynamics (Malačič and Petelin 2001) due to freshwater input, mainly from Isonzo/Soča River, tidal dynamics (Cozzi et al. 2004; Malačič and Petelin 2009), and atmospheric forcing including bora winds (Cantoni et al. 2012; Turk et al. 2013). Previous work indicates that the Gulf of Trieste tends to be a $\mathrm{CO}_{2}$ sink during autumn and winter ( -2 to $3 \mathrm{~mol} \mathrm{~m}^{-2}$ year $^{-1}$ of $\mathrm{CO}_{2}$ ), and a source in the summer (86.3 $\mathrm{mmol} \mathrm{m}^{-2}$ day $^{-1}$; Turk et al. 2010), which is primarily due to $\mathrm{CO}_{2}$ degassing from warm surface waters (DeGrandpre et al. 2002) and by the degradation of organic matter produced during the spring bloom (Chen and Borges 2009).

The seasonal variability in carbonate system parameters in the Gulf of Trieste is driven by several factors such as $\mathrm{CO}_{2}$ uptake and release due to biological processes and the variability of river inputs. These factors were partially addressed by Turk et al. (2010) and Cantoni et al. (2012). They also showed that bora wind events (observed in late autumn) might 
play a role in short-term variability of $p \mathrm{CO}_{2}$ in the Gulf of Trieste, possibly due to mixing and advection of water masses (Turk et al. 2013). First results on the role of river inorganic C loads focused only on Isonzo/Soča River and indicated that plumes were generally associated with higher total alkalinity (TA) and $p \mathrm{CO}_{2}$ values, but the effects were quite variable in space and time (Cantoni et al. 2012).

In this paper, we examine the geochemistry of all four rivers discharging into the Gulf of Trieste, the Isonzo/Soča, Timavo/Reka, Rižana, and Dragonja, each with different geologic and hydrologic settings of their drainage basins. The majority of Slovenian rivers are $\mathrm{Ca}^{2+}-\mathrm{Mg}^{2+}-\mathrm{HCO}_{3}{ }^{-}$waters (Szramek et al. 2007, 2011), and this is the source of DIC to the Gulf of Trieste from the four rivers studied here. We focus on the influence of riverine inorganic $\mathrm{C}$ loads on the variability of the carbonate system in the Gulf of Trieste and thus the sensitivity of the Northern Adriatic Sea to acidification. Moreover, we estimate the contribution of river sources of $\mathrm{CO}_{2}$ using stable $\mathrm{C}$ isotopes and ancillary chemical data (alkalinity, $\mathrm{Ca})$.

\section{Materials and Methods}

\section{Study Site}

The study site (22 $\mathrm{m}$ deep) at the coastal buoy VIDA $\left(45^{\circ} 32^{\prime}\right.$ $55.68^{\prime \prime} \mathrm{N}, 13^{\circ} 33^{\prime} 1.89^{\prime \prime} \mathrm{E}$; Fig. 1) is located in the southeastern part of the Gulf of Trieste $2 \mathrm{~km}$ from the shore in an area less affected by direct riverine inflows. The Gulf of Trieste is a semi-enclosed basin with an area of approximately $500 \mathrm{~km}^{2}$ and a maximum depth of only $25 \mathrm{~m}$ in the northeastern part of the Adriatic Sea. Meteorological conditions greatly influence the seawater $\mathrm{T}$, salinity and water column stratification (Malačič and Petelin 2001). The salinity of surface waters in the Gulf ranges between 30 (in spring during high riverine discharge) and 38 , and $\mathrm{T}$ from $8{ }^{\circ} \mathrm{C}$ (February) to $26{ }^{\circ} \mathrm{C}$ (August) (Faganeli et al. 2009). Vertical T and salinity gradients in late summer often result in bottom water hypoxia and occasionally anoxia. Conversely, during winter the water column is well mixed due to surface cooling and strong bora wind events. The main circulation is cyclonic and the outflow of seawater mostly occurs along the shallow northern coast after mixing with river waters (Solidoro et al. 2009).

The Isonzo/Soča River enters at the northern part of the Gulf of Trieste and is the most significant source of freshwater and nutrients to the Gulf (Cozzi et al. 2012). It has a length of $136 \mathrm{~km}$ with a drainage basin of $3,452 \mathrm{~km}^{2}$ and an average flow of $149 \mathrm{~m}^{3} \mathrm{~s}^{-1}$ (Szramek et al. 2011). The Isonzo/Soča watershed is composed mainly of karstified Mesozoic limestones and dolomites, some of which are Triassic and Cretaceous sediments and dolomitized limestones (Pleničar et al. 2009). The second tributary to the Gulf is the Timavo River
(Reka), entering the Gulf of Trieste on the northern side with an average flow of $27 \mathrm{~m}^{3} \mathrm{~s}^{-1}$. The total length of the Timavo is $89 \mathrm{~km}$ and it flows for about $40 \mathrm{~km}$ along its lowest part through a poorly defined path under the Karst Plateau. The springs of Timavo are one of the highest-discharge systems in the Mediterranean region. The Timavo springs receive most of their water through subterranean flow from the Reka River (Slovenia), with smaller contributions originating also from the underground waters of Vipava, Isonzo/Soča, and Raša (Civita et al. 1995). The Timavo flows through the Cretaceous-Tertiary limestone massif, which constitutes the classic Trieste Karst plateau (Pleničar et al. 2009).

Smaller coastal rivers entering the Gulf of Trieste on its eastern side are Rižana (discharging in the Bay of Koper) and Dragonja (discharging in the Bay of Piran). They have smaller drainage basins with 212 and $91 \mathrm{~km}^{2}$, lengths of 14 and $27 \mathrm{~km}$, respectively, and average flows of 4.0 and $1.1 \mathrm{~m}^{3} \mathrm{~s}^{-1}$, respectively. Both the Rižana and Dragonja rivers have an effect on primary production in the marine ecosystem due to their relatively significant input of terrestrial nutrients, especially nitrates and silica (Cozzi et al. 2012; Tamše et al. 2014). The Rižana features a karstic hinterland with a predominantly flysch area. Cretaceous sediments are comprised of carbonate rocks, older Tertiary strata partially from limestone and partially from clastic rock interbeds in flysch-like strata (Pleničar et al. 2009). The Dragonja catchment is mainly composed of impermeable Eocene flysch consisting of alternating, calcareous clay, silt and sandstone layers, with some calcareous conglomerates and breccias (Pleničar et al. 2009). All four rivers have typical Mediterranean flow regimes with their highest average discharges in spring and autumn, and the lowest in summer (Hrvatin 1998). High discharge periods are due to intense precipitation and snow-melt in the mountainous portion of the Isonzo/Soča drainage basin.

\section{Samples}

Surface water samples were taken in polyethylene bottles from the Isonzo/Soča, Timavo/Reka, Rižana, and Dragonja Rivers at representative typical riverine locations (Fig. 1) in May and October 2007 to capture the highest seasonal discharges. Seawater samples were collected at $2.7 \mathrm{~m}$ depth near the coastal buoy VIDA (Fig. 1) using 5-1 Niskin bottles, mounted on a Rosette sampler from March to November 2007 at approximately weekly intervals.

Sample aliquots for chemical analysis (TA, concentrations of $\mathrm{Ca}, \mathrm{Mg}, \mathrm{Cl}^{-}$, and the isotopic composition of dissolved inorganic carbon $\left.\left(\delta^{13} \mathrm{C}_{\mathrm{DIC}}\right)\right)$ were filtered through a $0.45-\mu \mathrm{m}$ Millipore HA membrane filter into their respective bottles and kept cold until analyzed. Acid-washed high-density polyethylene (HDPE) bottles were used to collect samples for $\mathrm{Ca}$ and $\mathrm{Mg}$ aliquots. These samples were preserved in the field with $\mathrm{HNO}_{3}$. Double deionized (DD) water-rinsed HDPE bottles 

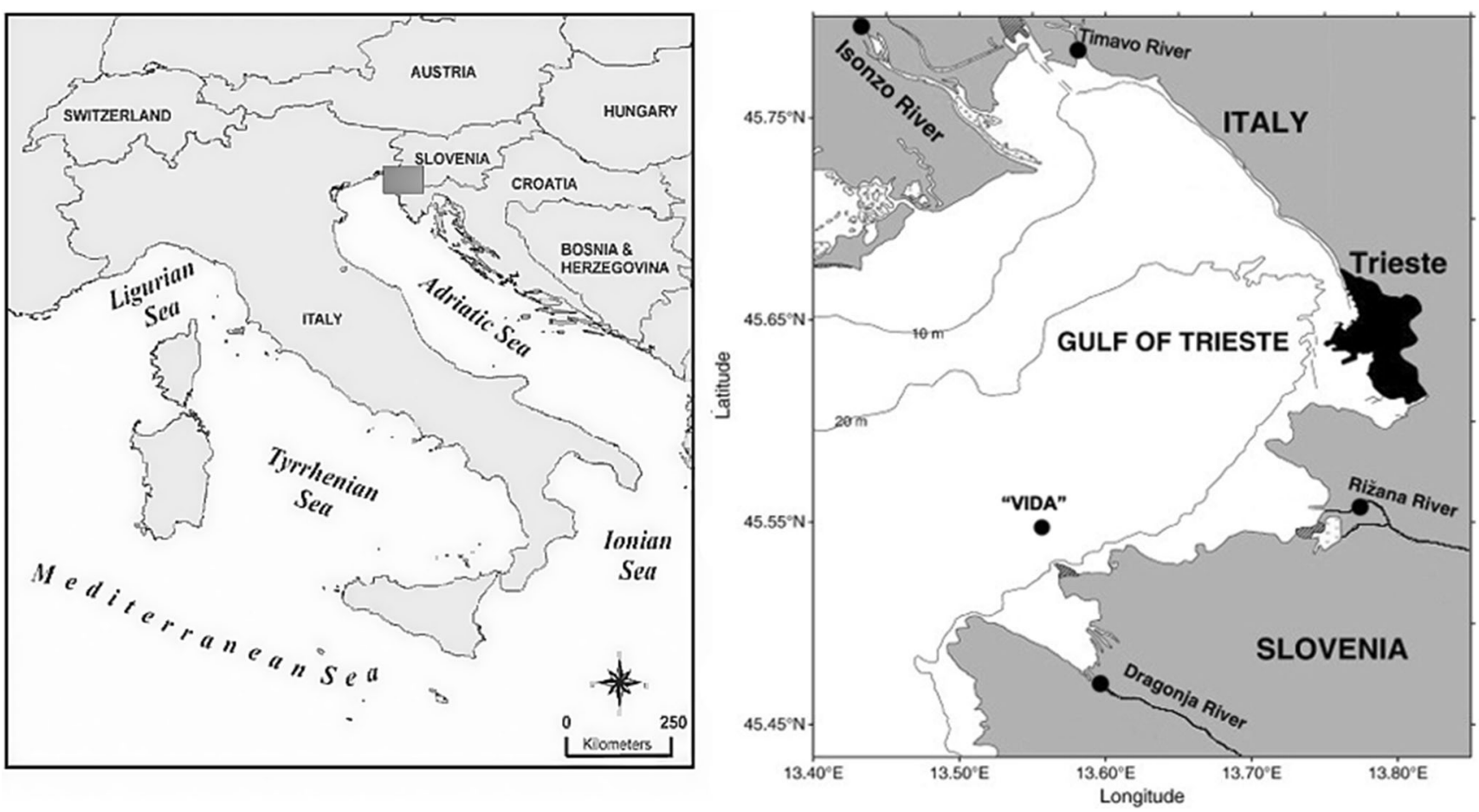

Fig. 1 Location of the study site at the coastal buoy VIDA in the Gulf of Trieste (northern Adriatic Sea). The sampling points in rivers are also marked

were used to collect samples for TA and $\mathrm{Cl}^{-}$. $\mathrm{HCl}$-washed glass serum bottles capped by Teflon liners were used to store samples for $\delta^{13} \mathrm{C}_{\mathrm{DIC}}$.

\section{Analyses}

$\mathrm{T}$, conductivity (EC), dissolved oxygen (DO), and $\mathrm{pH}$ were measured in situ. T and DO were measured directly in the river stream using a YSI model 58 meter, whereas EC was measured using a Corning 316 meter with a two-point calibration of 0 and $1,413 \mu \mathrm{S} \mathrm{cm}^{-1}$ with the precision of $\pm 5 \%$. A YSI 5239 DO probe with high-sensitivity membranes was used for DO measurements with a precision of $\pm 5 \%$. A Corning 315 high-sensitivity $\mathrm{pH}$ meter with an Orion Ross combination $\mathrm{pH}$ electrode, calibrated with low ionic strength buffers of 4.10 and 6.97, was used to measure $\mathrm{pH}$ in the river samples with a reproducibility of $\pm 0.02 \mathrm{pH}$ units. The $\mathrm{pH}$ measurements of seawater samples were performed on board, calibrated relative to the Tris seawater standard. In parallel, continuous measurements of sea surface salinity (SSS) and sea surface temperature (SST) were performed at the depth of $2.7 \mathrm{~m}$ at VIDA. For SSS, an Idronaut probe (OS 316) was used until July 2007, which was then replaced by a Sea-Bird Seacat CT probe. Total alkalinity in rivers $\left(\mathrm{TA}_{\mathrm{R}}\right)$ and in the Gulf of Trieste $\left(\mathrm{TA}_{\mathrm{GOT}}\right)$ was determined immediately after collection on shore by Gran titration (Millero et al. 1993). Accuracy for seawater samples was checked by titration of reference seawater (certified reference material for DIC and TA, Scripps Institute of Oceanography, USA). The precision of measurements was $\pm 1 \%$.
Samples for stable isotope composition of dissolved inorganic carbon $\left(\delta^{13} \mathrm{C}_{\text {DIC }}\right)$ were prepared by injecting the water sample into evacuated septum tubes with phosphoric acid. Released $\mathrm{CO}_{2}$ gas was then analyzed with a continuous-flow isotope ratio mass spectrometer (Europa 20-20 with ANCA TG trace gas separation module). Stable isotopic results are reported with $\delta$ values as deviations in per million from the VPDB standard. To determine the optimal extraction procedure for water samples a standard $\mathrm{Na}_{2} \mathrm{CO}_{3}$ solution was prepared with a known $\delta^{13} \mathrm{C}$ value of $-10.8 \pm 0.2 \%$. The precision based on replicate analysis was $\pm 0.2 \%$ for $\delta^{13} \mathrm{C}_{\text {DIC }}$.

Analysis of $\mathrm{Ca}$ and $\mathrm{Mg}$ were performed by inductively coupled plasma optical emission spectroscopy (ICP-OES) Jobin Yvon Horiba Ultima 2C, whereas $\mathrm{Cl}^{-}$was analyzed on a Dionex ICS-2500 IC. Analytical precision of these measurements was $\pm 2 \%$.

\section{Calculations}

The thermodynamic computation for the marine system was performed based on the experimental data of $\mathrm{pH}, \mathrm{TA}, \mathrm{SSS}$, $\mathrm{SST}$, and depth with the $\mathrm{CO} 2$ calc program (Robbins et al. 2010) with the first and second acidity constants for $\mathrm{CO}_{2}$ of Lueker et al. (2000) and the boric acid acidity constant and $\mathrm{HSO}_{4}$ of Dickson $(1990 \mathrm{a}, \mathrm{b})$. The partial pressure of $\mathrm{CO}_{2}$ $\left(p \mathrm{CO}_{2}\right)$, DIC, and mineral saturation state in rivers were determined using the PHREEQC speciation program (Parkhurst and Appelo 1999). The estimated uncertainties 
for the computed values were $\pm 1.5 \%$ for $p \mathrm{CO}_{2}, \pm 0.3$ for DIC, and $\pm 1.5 \%$ for calcium carbonate saturation states.

The thermal and non-thermal effects on marine surface $p \mathrm{CO}_{2}$ at VIDA were estimated by the model of Takahashi et al. (2002) and tested for the coastal waters including the Gulf of Trieste (Cantoni et al. 2012). The thermal effect on $p \mathrm{CO}_{2}\left(p \mathrm{CO}_{2, \mathrm{~T}}\right)$ represents the change in $p \mathrm{CO}_{2}$, which is caused solely by thermal forcing with constant chemical composition. The effect of T changes on $p \mathrm{CO}_{2}$ has been computed using the mean annual $p \mathrm{CO}_{2}$ of $377 \mu$ atm with the difference between the mean and observed T according to the following equation (Takahashi et al. 2002):

$$
\left(p \mathrm{CO}_{2, \mathrm{~T}} \text { at } \mathrm{SST}_{\mathrm{obs}}\right)=\left(p \mathrm{CO}_{2}\right)_{\text {mean }} \exp \left[0.0423\left(\mathrm{SST}_{\mathrm{obs}}-\mathrm{SST}_{\text {mean }}\right)\right]
$$

where the subscripts "mean" and "obs" indicate the annual average and observed values, respectively. $\left(p \mathrm{CO}_{2}\right)_{\mathrm{obs}}$ is the calculated $p \mathrm{CO}_{2}$ value (with $\mathrm{CO} 2$ calc program) at in situ conditions. In our calculation, the mean annual $\mathrm{T}, \mathrm{SST}_{\text {mean }}$ of $16.8{ }^{\circ} \mathrm{C}$ was used. The nonthermal effect on $p \mathrm{CO}_{2}(p$ $\mathrm{CO}_{2, \mathrm{NT}}$ ) includes all physical and biochemical processes that may influence the $\mathrm{CO}_{2}$ concentrations in the marine environment, such as advection, vertical mixing, air-sea $\mathrm{CO}_{2}$ exchange, primary production, and respiration. To remove the $\mathrm{T}$ effect from the observed $p \mathrm{CO}_{2}$, the observed $p \mathrm{CO}_{2}$ values are normalized to a constant $\mathrm{T}$ of $16.8^{\circ} \mathrm{C}$, the mean annual $\mathrm{T}$ of seawater. $p \mathrm{CO}_{2, \mathrm{NT}}$ is thus defined as a change in $p \mathrm{CO}_{2}$ due to changes in DIC concentration at a fixed SST according to (Takahashi et al. 2002):

$p \mathrm{CO}_{2, \mathrm{NT}}=\left(p \mathrm{CO}_{2}\right)_{\mathrm{obs}} \exp \left[0.0423\left(\mathrm{SST}_{\text {mean }}-\mathrm{SST}_{\mathrm{obs}}\right)\right]$.

The thermal $\left(\delta p \mathrm{CO}_{2, \mathrm{~T}}\right)$ and nonthermal effect $\left(\delta p \mathrm{CO}_{2, \mathrm{NT}}\right)$ are presented as the difference between the values presented in Cantoni et al. (2012) for $p \mathrm{CO}_{2, \mathrm{~T}}=251 \mu \mathrm{atm}, p \mathrm{CO}_{2, \mathrm{NT}}=$ $423 \mu \mathrm{atm}$ and $p \mathrm{CO}_{2}=315 \mu \mathrm{atm}$. These values were chosen as a reference to present the conditions of low $\mathrm{T}\left(9.8^{\circ} \mathrm{C}\right)$, minimum of biological processing, and negligible advection of river waters $(S=37.8)$. Similar conditions related to SST $\left(9.2^{\circ} \mathrm{C}\right)$ and SSS (37.3) were also observed in January 2007 at VIDA.

The isotopic effects involving photosynthetic utilization of $\mathrm{CO}_{2}$ or outgassing can be described by Rayleigh distillation equation for equilibrium. The isotopic composition resulting from a single output could be described with the following equation (Spiker and Schemel 1979):

$$
\delta^{13} \mathrm{C}_{\text {DIC }, \text { res }}=\left[\delta^{13} \mathrm{C}_{\mathrm{DIC}, \mathrm{i}}+1,000(1-\mathrm{f})^{\left(\frac{1}{\alpha_{\mathrm{so}}}-1\right)}\right]-1,000
$$

where $\delta^{13} \mathrm{C}_{\text {DIC,res }}$ and $\delta^{13} \mathrm{C}_{\mathrm{DIC}, \mathrm{i}}$ are the isotopic composition of DIC in the residual ("res") and initial ("i") solution, respectively, " $\mathrm{f}$ " is the fraction of $\mathrm{C}$ removed from the solution and is the only unknown in the equation that has to be calculated. $\alpha_{\text {so }}$ is the fractionation factor between solution (s) and the output species (o): $\alpha_{\text {so }}=R_{s} / R_{o}$, where $\mathrm{R}$ is ${ }^{13} \mathrm{C} /{ }^{12} \mathrm{C}$ ratio of each (DIC as solution (s) and POC as output species (o)).

The annual average flux of DIC, $\mathrm{F}_{\mathrm{DIC}, \mathrm{R}}$, from rivers have been calculated using the mean annual daily discharge for 2007, combined with the observed fluxes based on instantaneous DIC concentrations and instantaneous discharge values. This method can be used in the systems where DIC concentrations do not show a strong relationship with discharge (Hélie et al. 2002). The equation is as follows (Ogrinc et al. 2008):

$$
\mathrm{F}_{\mathrm{DIC}, \mathrm{R}}=\overline{\mathrm{Q}}\left[\frac{\sum_{i=1}^{n} \mathrm{C}_{\mathrm{DIC}, i} \mathrm{Q}_{i}}{\sum_{i=1}^{n} \mathrm{Q}_{i}}\right]
$$

where $\mathrm{F}_{\mathrm{DIC}, \mathrm{R}}$ is the annual flux (mol), $\overline{\mathrm{Q}}$ is the mean annual discharge rate $\left(\mathrm{m}^{3} / \mathrm{s}\right), \mathrm{C}_{\mathrm{DIC}, \mathrm{i}}$ is the instantaneous DIC concentration (calculated from TA during the sampling period; $\mathrm{mmol} / \mathrm{l})$ and $\mathrm{Q}_{\mathrm{i}}$ is the instantaneous discharge rate $\left(\mathrm{m}^{3} / \mathrm{s}\right)$.

The isotope conservative mixing curve connects concentrations of DIC and $\delta^{13} \mathrm{C}_{\mathrm{DIC}}$ values in the river and seawater according to the following equation:

$\delta^{13} \mathrm{C}_{\mathrm{DIC}, \mathrm{MIX}}=\frac{\delta^{13} \mathrm{C}_{\mathrm{DIC}, \mathrm{R}} \times \mathrm{f} \times \mathrm{C}_{\mathrm{DIC}, \mathrm{R}}+\delta^{13} \mathrm{C}_{\mathrm{DIC}, \mathrm{M}} \times(1-\mathrm{f}) \times \mathrm{C}_{\mathrm{DIC}, \mathrm{M}}}{\mathrm{C}_{\mathrm{DIC}, \mathrm{MIX}}}$

where $\mathrm{C}_{\mathrm{DIC}, \mathrm{MIX}}, \mathrm{C}_{\mathrm{DIC}, \mathrm{M}}$, and $\mathrm{C}_{\mathrm{DIC}, \mathrm{R}}$ are concentrations of DIC in the mixture (MIX), marine (M), and river $(\mathrm{R})$ end-member and $\delta^{13} \mathrm{C}_{\text {DIC,MIX }}, \delta^{13} \mathrm{C}_{\text {DIC,M }}$, and $\delta^{13} \mathrm{C}_{\text {DIC,R }}$ are corresponding $\delta^{13} \mathrm{C}$ values. The fraction of river water, $\mathrm{f}$, is calculated from the salinity.

The contribution to the $\delta^{13} \mathrm{C}_{\mathrm{DIC}, \mathrm{GOT}}$ from riverine and marine sources was estimated using the isotope mass balance with the following relations:

$\delta^{13} \mathrm{C}_{\mathrm{DIC}, \mathrm{GOT}}=\mathrm{F}_{\mathrm{M}} \delta^{13} \mathrm{C}_{\mathrm{DIC}, \mathrm{M}}+\mathrm{F}_{\mathrm{R}} \delta^{13} \mathrm{C}_{\mathrm{DIC}, \mathrm{R}}$

$1=\mathrm{F}_{\mathrm{M}}+\mathrm{F}_{\mathrm{R}}$

where $F_{M}$ and $F_{R}$ are the respective marine and riverine fractions. For this calculation, two different end-members were required. $\delta^{13} \mathrm{C}_{\mathrm{DIC}, \mathrm{R}}$ average values found at the rivers were taken as riverine end-members, whereas as the marine end-member $\left(\delta^{13} \mathrm{C}_{\mathrm{DIC}, \mathrm{M}}\right)$, the average $\delta^{13} \mathrm{C}_{\text {DIC }}$ value of $0.6 \%$ for world surface seawater was assumed (Kroopnick 1985).

\section{Data Analysis}

Data were analyzed by ANOVA and Tukey's test ( $\alpha=5 \%$ ) to test for the differences in water chemistry and stable isotope values according to the season and locations. Both the oneway ANOVA and the two-way ANOVA were performed on ranked data. In all statistical tests, probability $(p)$ values of less than 0.05 were used to indicate the significance level. All 
statistical analyses were run using STATISTICA software package v.7 (StatSoft Inc., Tulsa, OK, USA).

\section{Results}

Carbonate System Variability in the Riverine System

Geochemical and discharge data from rivers are presented in Table 1. The $\mathrm{pH}_{\mathrm{R}}$ ranged from 6.64 to 8.27 with the highest observed in the Rižana in October 2007. Differences in $\mathrm{pH}$ values between seasons were not significant $(p=0.244)$ nor were the differences between rivers $(p=0.161)$. Higher T in all rivers was observed in May relative to October in 2007 except for the Timavo/Reka; however, no statistical difference between seasons were observed $(p=0.167)$. Likewise, the differences between the observed $\mathrm{T}$ in rivers were non-significant ( $p=0.824)$. The $\mathrm{O}_{2}$ content ranged from 7.8 to $13.1 \mathrm{mg} \mathrm{l}^{-1}$ and non-significant differences were observed between seasons or rivers $(p=0.796, p=0.173$ ). Specific EC varied from 274 to $464 \mu \mathrm{S} \mathrm{cm}^{-1}$, indicative of freshwater, except in the Dragonja where EC reached up to $7,490 \mu \mathrm{S} \mathrm{cm}^{-1}$ indicating seawater intrusion into the river during both sampling periods. The seawater intrusion was also supported by higher concentrations of $\mathrm{Cl}_{\mathrm{R}}^{-}$and $\mathrm{Mg}_{\mathrm{R}}$ observed in May 2007; therefore, these data were excluded from further interpretation. The seasonal effect was non-significant for EC $(p=0.910)$, but differences among the observed levels in rivers were significant $(p=$ 0.023). The $\mathrm{TA}_{\mathrm{R}}$ ranged from 2.96 to $5.12 \mathrm{mmol} \mathrm{l}^{-1}, \mathrm{Ca}_{\mathrm{R}}$ concentrations ranged from 1.14 to $2.70 \mathrm{mmol} \mathrm{l}^{-1}$ and $\mathrm{Mg}_{\mathrm{R}}$ concentrations from 0.23 to $5.30 \mathrm{mmol} \mathrm{l}^{-1}$. The $\delta^{13} \mathrm{C}_{\mathrm{DIC}, \mathrm{R}}$ values ranged from -12.8 and $-7.7 \%$ with the highest values observed in the Isonzo/Soča and the lowest in the Rižana in October 2007. There was no significant statistical difference in levels of $\mathrm{TA}_{\mathrm{R}}(p=0.511), \mathrm{Ca}_{\mathrm{R}}(p=0.419), \mathrm{Mg}_{\mathrm{R}}(p=0.428)$, and $\delta^{13} \mathrm{C}_{\mathrm{DIC}, \mathrm{R}}(p=0.392)$ between seasons. Conversely, the differences in the observed $\mathrm{TA}_{\mathrm{R}}, \mathrm{Ca}_{\mathrm{R}}$, and $\mathrm{Mg}_{\mathrm{R}}$ levels between rivers were significant ( $p=0.003, p=0.008, p<0.001$ ). The obtained results suggest that $\mathrm{EC}, \mathrm{TA}_{\mathrm{R}}, \mathrm{Ca}_{\mathrm{R}}$, and $\mathrm{Mg}_{\mathrm{R}}$ are different in rivers, but did not change with season, whereas $\mathrm{pH}, \mathrm{T}$, and $\delta^{13} \mathrm{C}_{\mathrm{DIC}, \mathrm{R}}$ did not show differences related to season or to river. Two-way ANOVA was used to compare the results from different seasons, using the river as the second independent variable to control for variation between sites. There was a significant interaction effect between season and rivers with regards to levels of $\mathrm{pH}, \mathrm{TA}_{\mathrm{R}}, \mathrm{Ca}_{\mathrm{R}}$ and $\mathrm{Mg}_{\mathrm{R}}(F=$ 20.02, $p=0.048 ; F=49.54, p=0.019 ; F=81.74, p=0.012 ; F=$ 928.8, $p=0.001)$.

Riverine mass transport of DIC is influenced by the saturation state of carbonate minerals and the riverine discharge. The discharge of the four rivers in 2007 is presented in Fig. $3 a$. Mean daily flows of all rivers Dragonja, Rižana, Timavo/ Reka, and Isonzo/Soča showed marked fluctuations with the highest flows recorded in autumn, whereas the increase in the Isonzo/Soča discharge was also observed in June 2007. The carbonate weathering intensity in rivers was estimated, since it quantifies the amount of DIC produced from mineral weathering with $\mathrm{CO}_{2}$ normalized to drainage area (discharge per unit area of the watershed- "specific runoff"). Combining the data from the Slovenian Environment Agency (ARSO; http://www.arso.gov.si/vode/podatki/arhiv/kakovost_ arhiv2009.html) with the results of our own sampling study has allowed discharge comparisons to be made for the rivers draining into the Gulf of Trieste. Importantly, DIC concentrations in rivers depicted a weak seasonal effect and were not correlated with mean monthly discharges (Fig. 2a), and thus carbonate weathering intensity is a direct linear function of specific runoff and mass transfer rates increased proportionately with increasing water flux. River watersheds along the Gulf of Trieste typically have higher carbonate weathering intensities than the world average value of $7 \mathrm{mmol} \mathrm{km}^{-2} \mathrm{~s}^{-1}$ (Szramek et al. 2007). The highest carbonate weathering intensity of $159 \mathrm{mmol} \mathrm{km}^{-2} \mathrm{~s}^{-1}$ was determined in the Timavo in May, followed by the carbonate weathering intensity of $74 \mathrm{mmol} \mathrm{km} \mathrm{s}^{-2} \mathrm{~s}^{-1}$ in the Rižana in October. Both rivers are clearly dominated by calcite weathering. The Isonzo/Soča has slightly lower intensity of $58 \mathrm{mmol} \mathrm{km}^{-2} \mathrm{~s}^{-1}$ in May and $35 \mathrm{mmol} \mathrm{km} \mathrm{s}^{-2} \mathrm{~s}^{-1}$ in October, whereas the Dragonja has an intensity of $3 \mathrm{mmol} \mathrm{km}^{-2} \mathrm{~s}^{-1}$, and drains mainly silicate rocks. The difference between seasons and rivers was found to be non-significant for carbonate weathering intensity ( $p=0.675, p=0.328)$.

The $\delta^{13} \mathrm{C}_{\text {DIC, } \mathrm{R}}$ values suggested almost no dependence on water discharge (Fig. 2b) and classification into two groups. The Isonzo/Soča river has the highest $\delta^{13} \mathrm{C}_{\mathrm{DIC}, \mathrm{R}}$ and the highest temporal variation. The decrease in $\delta^{13} \mathrm{C}_{\mathrm{DIC}, \mathrm{R}}$ value to $-10.0 \%$ could be due to the respiration process. This river is, in terms of discharge, the most important source of freshwater in the Gulf of Trieste. The other three rivers (Dragonja, Rižana, and Timavo) have an average $\delta^{13} \mathrm{C}_{\mathrm{DIC}, \mathrm{R}}$ value of $-12.0 \%$ indicating more pronounced influence of biogenic $\mathrm{CO}_{2}$. The $p \mathrm{CO}_{2}$ of the surface waters range from 1,107 to $37,522 \mu \mathrm{atm}$ observed in the Rižana in October and the Dragonja in May 2007, respectively (Table 1). All rivers show $p \mathrm{CO}_{2}$ values that are on average 10 times higher than the atmospheric $p \mathrm{CO}_{2}$ and present significant variations in relation to discharge (Fig. 2c), however no significant difference was observed in $p \mathrm{CO}_{2}$ levels between seasons (one-way ANOVA; $F=2.15, p=0.202$ ). The surface waters were supersaturated for calcite and dolomite. Variable $\mathrm{Mg}_{\mathrm{R}} / \mathrm{Ca}_{\mathrm{R}}$ ratios were observed in rivers ranging from 0.11 to 0.88 (Table 1). The lowest values were observed in the Rižana and Timavo, while the highest were observed in the Dragonja.

The discharge of DIC was estimated to be $2.7 \times 10^{7}, 4.5 \times$ $10^{9}$, and $6.4 \times 10^{9} \mathrm{~g}$ for the Rižana, Timavo/Reka, and Isonzo/ Soča in May 2007, respectively, while in October 2007 the 

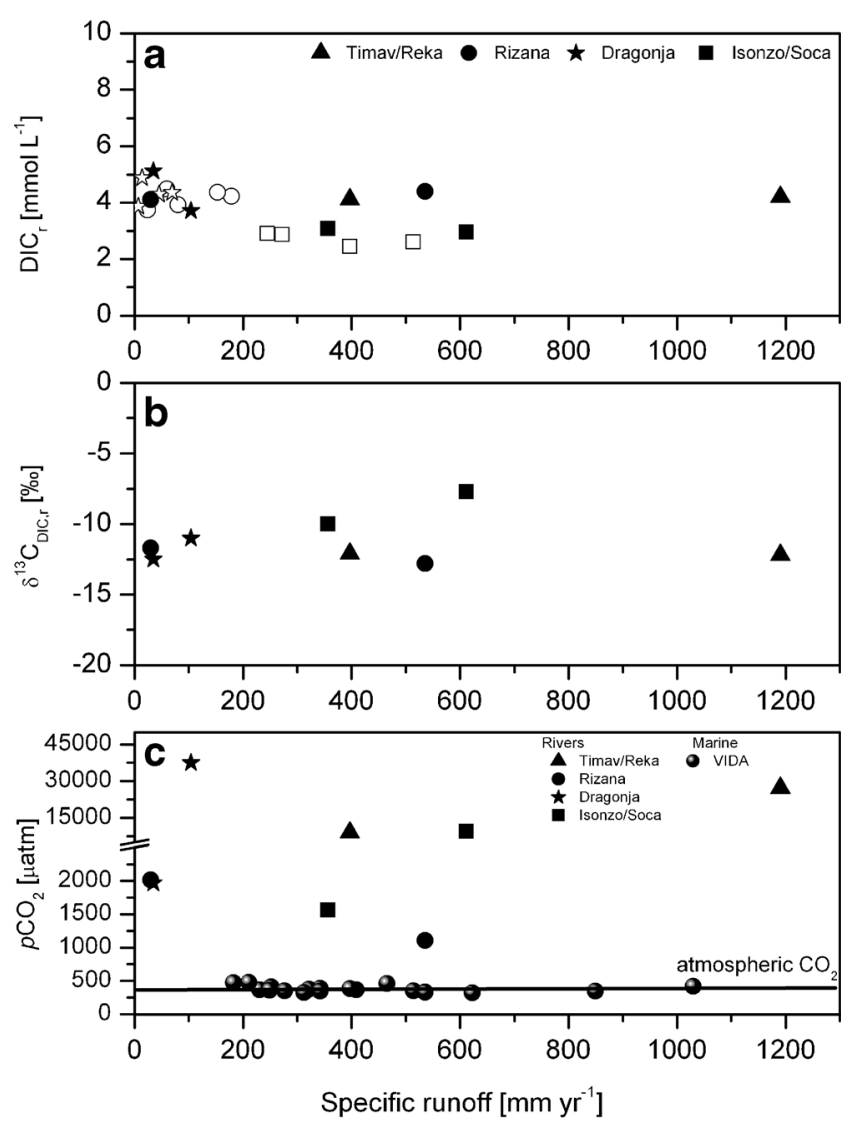

Fig. 2 Relationship between a the DIC concentrations (combining the data from the ARSO (open symbols) with results of our own study (solid symbols)); $\mathbf{b} \delta^{13} \mathrm{C}_{\mathrm{DIC}, \mathrm{R}}$ and $\mathbf{c} p \mathrm{CO}_{2}$ and the specific runoff intensity for four rivers discharging into the Gulf of Trieste (Dragonja, Rižana, Timavo/Reka, and Isonzo/Soča). Data obtained in 2007 at the VIDA station in the Gulf of Trieste are also presented

October 2007 (the most "acidic" with regard to carbonate saturation state) correlating with higher observed river discharges into the Gulf of Trieste.

The calculated $p \mathrm{CO}_{2}$ values at VIDA ranged from 318 observed in March 2007 to $478 \mu$ atm at the end of August 2007, however, seasonal effects were non-significant for $p \mathrm{CO}_{2}\left(p=0.687\right.$ ) (Fig. 3e). The calculated $p \mathrm{CO}_{2}$ values using thermodynamic relations were comparable to the data obtained by Cantoni et al. (2012) at station PALOMA in the center of the Gulf of Trieste but were generally higher than the measured $p \mathrm{CO}_{2}$ values published in Turk et al. (2010) (Fig. 3e). Unfortunately, the data from June and July are not available precluding any comparison. Large differences were observed in spring (April and May), August 15 and late summer-early autumn 2007. It seems that the main cause of this discrepancy could be related to measurements (TA and $p \mathrm{CO}_{2}$ determination) and thermodynamic models, i.e., constants (McElligott et al. 1998). In addition, organic bases can account for small fraction of the titrated alkalinity (Millero et al. 1993; Hernándes-Ayon et al. 2007) and thus influence the thermodynamic calculation leading to higher $p \mathrm{CO}_{2}$ values. In this context, the highest concentrations of DOC in the Gulf waters of about $0.1 \mathrm{mM}$ appeared in summer-early autumn period (De Vittor et al. 2008) in parallel with high bacterial abundance and production (Fonda Umani et al. 2007). In March 2007 , higher photosynthesis led to low $p \mathrm{CO}_{2}$ values and there was almost no difference observed between measured and calculated $p \mathrm{CO}_{2}$ values.

\section{Discussion}

Temperature vs. Biological Effects

The method proposed by Takashi et al. (2002) was applied in order to better understand the relative importance of $\mathrm{T}$ changes and $\mathrm{CO}_{2}$ production/uptake on variations of $p \mathrm{CO}_{2}$ (Eqs. 1 and 2) at VIDA station in the Gulf of Trieste. The normalized $\delta p \mathrm{CO}_{2, \mathrm{~T}}, \delta p \mathrm{CO}_{2, \mathrm{NT}}$, and $\delta p \mathrm{CO}_{2}$ values are presented in Fig. 4. The $\delta p \mathrm{CO}_{2, \mathrm{~T}}$ reached the highest value of $317 \mu \mathrm{atm}$ at the end of July 2007 indicating that the increase of T would cause the increase of $p \mathrm{CO}_{2}$ of $317 \mu \mathrm{atm}$ at the constant chemical composition of seawater. The decrease of $\delta p \mathrm{CO}_{2, \mathrm{~T}}$ from 296 to $239 \mu \mathrm{atm}$ was observed in the second part of July due to the presence of Isozo/Soča River plumes (Fig. 4a, c). The presence of river plumes were further supported by the lower $\delta^{13} \mathrm{C}_{\mathrm{DIC}, \mathrm{GOT}}$ value of $-0.27 \%$. In addition the $\delta p \mathrm{CO}_{2, \mathrm{~T}}$ values started to decrease in late August 2007 and continued to decrease until the end of the sampling period. This trend could not be explained only by $\mathrm{T}$ and may be the consequence of other processes such as phytoplankton uptake and in autumn the presence of freshwaters (Fig. 4a).

$\delta p \mathrm{CO}_{2, \mathrm{NT}}$ levels increased reaching the highest value in April 2007 and after this period a decrease in $\delta p \mathrm{CO}_{2, \mathrm{NT}}$ was noticed influenced by biological activity. Phytoplankton biomass, as indicated by chlorophyll $a(\mathrm{Chl} a)$ concentrations, was relatively high at the same period (SeaWiFS Chl $a$; Turk et al. 2010). In addition, the highest $\delta^{13} \mathrm{C}_{\mathrm{DIC}, \mathrm{GOT}}$ value of 1.3 \%o was observed indicating a net utilization of ${ }^{12} \mathrm{CO}_{2}$ during photosynthesis resulting in a ${ }^{13} \mathrm{C}$-enrichment of the water reservoir. In a number of case studies elevated, $\delta^{13} \mathrm{C}_{\text {DIC }}$ values were linked to primary production (Bouillon et al. 2011), for example, the seasonal $\delta^{13} \mathrm{C}_{\mathrm{DIC}}$ data presented by Gillikin et al. (2006) for the Scheldt estuary show higher $\delta^{13} C_{\text {DIC }}$ values during phytoplankton bloom periods. $\mathrm{CO}_{2}$ uptake can be estimated by Eq. 3 from $\delta^{13} \mathrm{C}_{\mathrm{DIC}, \mathrm{GOT}}$ values in solutions before ("initial" solution) and after ("residual" solution) the phytoplankton bloom. In this calculation, we assumed that the $\delta^{13} \mathrm{C}$ of biogenic (utilized) C (POC) was $-24 \%$. This value was found to be representative $\delta^{13} \mathrm{C}$ value for POC in spring (Faganeli et al. 2009). $\mathrm{CO}_{2}$ uptake was about $45 \pm 10 \mu \mathrm{mol} \mathrm{l}^{-1}$ from April to May 2007. Scaled to the whole water column, this amounts to $0.72 \mathrm{~g} \mathrm{C} \mathrm{m}^{-2}$ day $^{-1}$. These estimates are in the same order of magnitude as the net primary production (NPP) 
Table 2 Temperature, salinity, and inorganic carbon parameters together with the isotopic composition of dissolved inorganic carbon $\left(\delta^{13} \mathrm{C}_{\mathrm{DIC}}\right)$ at $\mathrm{VIDA}$ site in the Gulf of Trieste (N Adriatic)

\begin{tabular}{|c|c|c|c|c|c|c|c|c|c|c|c|}
\hline Date & $\begin{array}{l}\mathrm{T} \\
\left({ }^{\circ} \mathrm{C}\right)\end{array}$ & $\mathrm{S}$ & $\mathrm{pH}$ & $\begin{array}{l}\text { TA } \\
\left(\mathrm{mmol} 1^{-1}\right)\end{array}$ & $\begin{array}{l}\mathrm{DIC} \\
\left(\mathrm{mmol} 1^{-1}\right)\end{array}$ & $\begin{array}{l}\delta^{13} \mathrm{C}_{\mathrm{DIC}} \\
(\% \mathrm{o})\end{array}$ & $\begin{array}{l}\mathrm{Ca} \\
\left(\mathrm{mmol} 1^{-1}\right)\end{array}$ & $\begin{array}{l}\mathrm{Mg} \\
\left(\mathrm{mmol} \mathrm{1} \mathrm{l}^{-1}\right)\end{array}$ & 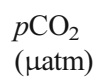 & $\begin{array}{l}\Omega_{\text {calc }} \\
(\mathrm{IAP} / \mathrm{K})\end{array}$ & $\begin{array}{l}\Omega_{\text {arg }} \\
(\mathrm{IAP} / \mathrm{K})\end{array}$ \\
\hline 16 Mar 2007 & & & & 3.150 & & -1.8 & 8.01 & 41.10 & & & \\
\hline 28 Mar 2007 & 11.8 & 35.4 & 8.25 & 2.777 & 2.752 & -2.2 & n.d. & 71.17 & 318 & 6.95 & 4.45 \\
\hline 13 Apr 2007 & 16.7 & 34.5 & 8.07 & 2.967 & 2.493 & 0.1 & 8.26 & 42.19 & 462 & 5.05 & 3.26 \\
\hline 29 May 2007 & 21.4 & 35.2 & 8.13 & 2.758 & 2.576 & 1.3 & 7.98 & 40.94 & 416 & 6.94 & 4.54 \\
\hline 6 Jun 2007 & 20.8 & 36.5 & 8.13 & 2.701 & 2.394 & -0.4 & 12.08 & 62.21 & 387 & 6.14 & 4.12 \\
\hline 12 Jun 2007 & 22.4 & 36.3 & 8.14 & 2.670 & 2.320 & -0.4 & 12.16 & 61.78 & 367 & 6.58 & 4.32 \\
\hline 20 Jun 2007 & 24.6 & 35.0 & 8.13 & 2.816 & 2.287 & -1.3 & 12.08 & 61.18 & 375 & 6.75 & 4.44 \\
\hline 3 Jul 2007 & 24.8 & 36.3 & 8.17 & 2.602 & 2.373 & 0.8 & 11.93 & 60.94 & 348 & 7.75 & 5.11 \\
\hline 10 Jul 2007 & 25.6 & 34.0 & 8.15 & 2.608 & 2.210 & -0.3 & 13.64 & 69.04 & 346 & 6.94 & 4.57 \\
\hline $15 \mathrm{Jul} ; 2007$ & 23.0 & 36.7 & 8.16 & 2.777 & 2.213 & 0.0 & 11.57 & 58.66 & 332 & 6.70 & 4.40 \\
\hline 22 Jul 2007 & 26.5 & 36.5 & 8.11 & 2.597 & 2.239 & 0.8 & 11.03 & 55.81 & 385 & 7.25 & 4.81 \\
\hline 29 Jul 2007 & 25.8 & 37.4 & 8.16 & 2.596 & 2.166 & 1.0 & 12.00 & 60.79 & 325 & 7.24 & 4.80 \\
\hline 6 Aug 2007 & 24.1 & 38.0 & 8.12 & 3.138 & 2.208 & 1.0 & 12.81 & 65.08 & 366 & 6.48 & 4.28 \\
\hline 15 Aug 2007 & 24.8 & 38.0 & 8.10 & 3.179 & 2.699 & 0.6 & 11.54 & 58.34 & 471 & 7.79 & 5.15 \\
\hline 23 Aug 2007 & 24.2 & 37.6 & 8.21 & 3.087 & 2.648 & 0.5 & 12.04 & 61.13 & 347 & 9.33 & 6.16 \\
\hline 28 Aug 2007 & 24.0 & 36.8 & 8.09 & 3.027 & 2.671 & 0.6 & 11.86 & 60.19 & 478 & 7.36 & 4.85 \\
\hline 4 Sep 2007 & 21.6 & 37.8 & 8.14 & 2.610 & 2.607 & 1.6 & 11.49 & 58.46 & 409 & 7.34 & 4.80 \\
\hline 11 Sep 2007 & 21.8 & 37.2 & 8.13 & 2.606 & 2.238 & 0.5 & 12.95 & 66.14 & 360 & 6.21 & 4.07 \\
\hline 30 Sep 2007 & 20.0 & 36.6 & 8.17 & 2.577 & 2.226 & 0.5 & 11.68 & 59.29 & 322 & 6.31 & 4.11 \\
\hline 15 Oct 2007 & 18.0 & 36.2 & 8.14 & 3.150 & 2.241 & -0.2 & 11.19 & 56.97 & 348 & 5.58 & 3.62 \\
\hline
\end{tabular}

measured in the Gulf of Trieste in late spring, $2 \mathrm{~g} \mathrm{C} \mathrm{m}^{-2}$ day $^{-1}$ (Fonda Umani et al. 2007). If the surface water had maintained the same T, the biological uptake acting from March to August 2007 would have produced a decrease of $p \mathrm{CO}_{2}$ of $221 \mu \mathrm{atm}$. However, surface $\delta p \mathrm{CO}_{2}$ and $\delta p \mathrm{CO}_{2, \mathrm{~T}}$ indicates that the thermal effect was still controlled by biological processes. The decrease in $\delta p \mathrm{CO}_{2, \mathrm{NT}}$ throughout the summer until the end of July 2007 could be mainly explained by biological processes and not by outgassing. The $p \mathrm{CO}_{2}$ was low throughout the summer to the end of July (Table 2; Fig. 2e) and the water was undersaturated with respect to $p \mathrm{CO}_{2}$ (Fig. 2c). In August 2007 , an increase in $\delta p \mathrm{CO}_{2, \mathrm{NT}}$ was observed probably influenced by the $\mathrm{CO}_{2}$ production during higher remineralization. This effect could not be seen in $\delta^{13} \mathrm{C}_{\mathrm{DIC}, \mathrm{GOT}}$ values. The input of biogenic $\mathrm{C}$ as POC is depleted in ${ }^{13} \mathrm{C}$ (approximately -20 $\%$; Faganeli et al. 2009) and would be expected to decrease the $\delta^{13} \mathrm{C}_{\mathrm{DIC}, \mathrm{GOT}}$, however, $\delta^{13} \mathrm{C}_{\mathrm{DIC}, \mathrm{GOT}}$ values decreased in about $0.3 \%$ and were within the measured uncertainty of \pm 0.2 $\%$.

In autumn, another decrease in $\delta p \mathrm{CO}_{2, \mathrm{NT}}$ was observed in relation to the second phytoplankton bloom occurring during October 2007 (SeaWiFS Chl $a$; Turk et al. 2010). However, the $\mathrm{CO}_{2}$ uptake estimated from $\delta^{13} \mathrm{C}_{\mathrm{DIC}, \mathrm{GOT}}$ was about $13 \pm$ $8 \mu \mathrm{mol} \mathrm{l}^{-1}$ (Eq. 3) from the end of August to September 2007 and lower relative to the spring data. In this calculation, the biogenic $\mathrm{C}$ was taken to be $-21 \%$ as a representative $\delta^{13} \mathrm{C}_{\mathrm{POC}}$ value in late summer (Faganeli et al. 2009). Scaled to the whole water column the $\mathrm{CO}_{2}$ uptake amounts to $0.1 \mathrm{~g}$ $\mathrm{C} \mathrm{m}^{-2}$ day $^{-1}$, which is in a good agreement with the results obtained from NPP measured in the Gulf of Trieste in autumn $\left(<1 \mathrm{~g} \mathrm{C} \mathrm{m}^{-1}\right.$ day $^{-1}$; Fonda Umani et al. 2007).

The relative importance of biological and $\mathrm{T}$ effects on the surface water $p \mathrm{CO}_{2}$ can be expressed as a ratio between the effect of $\mathrm{T}$ changes $\mathrm{T}=\left(p \mathrm{CO}_{2, \mathrm{~T}}\right)_{\max }-\left(p \mathrm{CO}_{2, \mathrm{~T}}\right)_{\min }$ and the effect of biological changes $\mathrm{B}=\left(p \mathrm{CO}_{2, \mathrm{NT}}\right)_{\max }-\left(p \mathrm{CO}_{2, \mathrm{NT}}\right)_{\min }$ (Takahashi et al. 2002). The months of March, June, and October 2007, characterized by high river inputs, were excluded from calculation. The resulting $\mathrm{T} / \mathrm{B}$ ratio was 1.31 in the Gulf of Trieste indicating a higher T effect. The ratio was comparable with the T/B ratio obtained by Cantoni et al. (2012) at station PALOMA. The ratio is also in agreement with the general observation that in temperate oceans of both hemispheres, the $\mathrm{T}$ effect exceeds the biologic effect (Takashi et al. 2002).

The Role of Riverine Inflows

The $\mathrm{Mg}_{\mathrm{R}} / \mathrm{Ca}_{\mathrm{R}}$ ratios in the Rižana and Timavo were around 0.11 indicating that more than $75 \%$ of the carbonate mineral weathering is calcite. Dissolution of equal masses of dolomite and calcite produce waters with a $\mathrm{Mg}_{\mathrm{R}} / \mathrm{Ca}_{\mathrm{R}}$ ratio of 0.33 , as observed in the Isonzo/Soča, whereas dolomite dissolution 


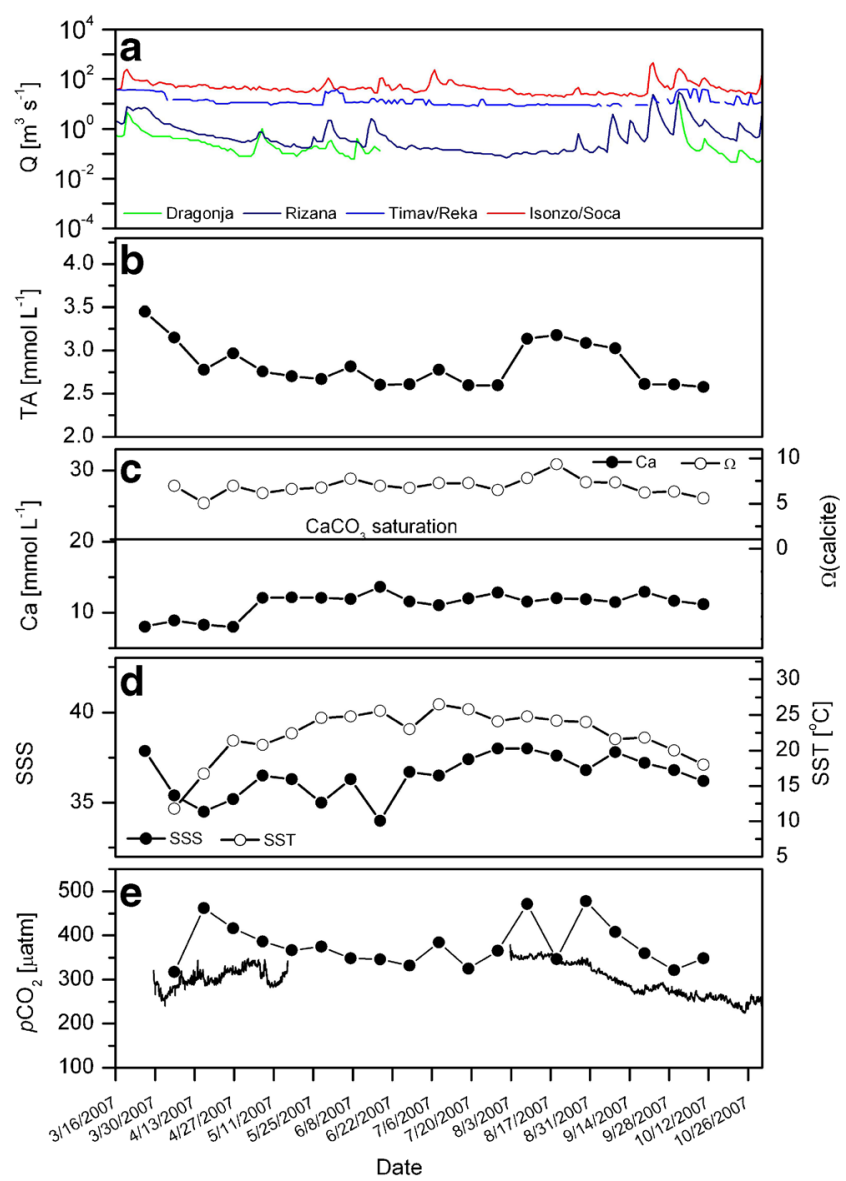

Fig. 3 a Daily mean discharges of Isonzo/Soča, Timavo/Reka, Rižana, and Dragonja during 2007. The data for the Isonzo/Soča were provided by Agenzia Regionale per la Protezione dell'Ambiente (ARPA) of the Region Friuli Venezia Giulia, whereas data for the Rižana and Dragonja were obtained from the ARSO. Flow rate data for the Timavo/Reka (Bocche di Timavo) were provided by AcegasAps. b Total alkalinity (TA) at the coastal buoy VIDA in the Gulf of Trieste. c Concentrations of $\mathrm{Ca}$ and the calculated saturation state $\left(\Omega_{\text {calcite }}\right)$ for $\mathrm{CaCO}_{3}$. The horizontal line represents an equilibrium value for $\mathrm{CaCO}_{3}$ (Mucci 1983). d Seawater surface salinity (SSS) and sea surface temperature (SST). e $p \mathrm{CO}_{2}$ during the sampling period March-November 2007 (Turk et al. 2010) and the calculated $p \mathrm{CO}_{2}$ values from this study using the $\mathrm{CO} 2$ calc program

produces waters with a $\mathrm{Mg}_{\mathrm{R}} / \mathrm{Ca}_{\mathrm{R}}$ ratio of 0.88 , as observed in the Dragonja. These ratios together with $\mathrm{TA}_{\mathrm{R}}$ (DIC) data do not change significantly with the river discharge (Fig. 2a) indicating rapid carbonate mineral weathering to the equilibrium point with the carbonate minerals available in the given river catchment, as discussed in Szramek et al. (2007) for other large river drainages in Slovenia and North America.

The influence of riverine inputs was observed at the seawater station VIDA in spring 2007 and coincided with the salinity drop, lower $\mathrm{Ca}_{\mathrm{GOT}}$ concentrations, higher $\mathrm{TA}_{\mathrm{GOT}}$ and lower $\delta^{13} \mathrm{C}_{\mathrm{DIC}, \mathrm{GOT}}$ values. It was found that at the same period daily discharge for the $\mathrm{N}$ Adriatic Rivers (Timavo/Reka, Isonzo/Soča, Dragonja and Rižana) increased (Fig. 3a). As suggested by Turk et al. (2010), the Timavo, which drains karst terrain, could be responsible for the observed decrease in salinity with a possible smaller contribution from Dragonja and Rižana. The stable isotope-based mixing model for conservative mixing in estuaries described by Eq. 5 can provide important insights into sources, sinks, and processing of DIC. Isotope mixing lines with marine and two different riverine end-members are presented in Fig. 5. A DIC concentration of $2.17 \mu \mathrm{mol}^{-1}$ and $\delta^{13} \mathrm{C}_{\mathrm{DIC}, \mathrm{GOT}}$ of $0.6 \%$ was chosen for the marine end-member. According to $\delta^{13} \mathrm{C}_{\mathrm{DIC}, \mathrm{R}}$, two different riverine end-members could be determined with a mean DIC concentration of $2.81 \mu \mathrm{mol} 1^{-1}$ and $\delta^{13} \mathrm{C}_{\mathrm{DIC}, \mathrm{R}}$ value of $-8.6 \%$ for the Isonzo/Soča and a mean DIC concentration of $4.27 \mu \mathrm{mol}^{-1}$ and $\delta^{13} \mathrm{C}_{\mathrm{DIC}, \mathrm{R}}$ value of $-12.2 \%$ for other three rivers (Dragonja, Rižana, and Timavo/Reka). In spring 2007, $\delta^{13} \mathrm{C}_{\mathrm{DIC}, \mathrm{GOT}}$ in the seawater surface varied from -2.2 to $1.3 \%$ and three points at salinities of 35.0, 36.3, and 36.5 fell close to the mixing line defined from three rivers. According to isotope mass balance (Eqs. 6 and 7), rivers contributed from 7 to $16 \%$ to DIC at the sampling station VIDA in June 2007. $\delta^{13} \mathrm{C}_{\mathrm{DIC}, \mathrm{GOT}}$ values were about $1.6 \%$ less than predicted by conservative mixing of seawater and river waters in March 2007 due to the biogenic $\mathrm{C}$ source such as respiration and mineralization. Conversely, $\delta^{13} \mathrm{C}_{\mathrm{DIC}, \mathrm{GOT}}$ values falling about the mixing line (the data from April and May 2007) were influenced by fractionation during photosynthesis. The biological uptake by the concomitant phytoplankton bloom (Turk et al. 2010) was further supported by the increase in $p \mathrm{CO}_{2}$ and $p \mathrm{CO}_{2, \mathrm{NT}}$.

The freshwater influence was again observed in July 2007 when the salinity dropped to 34 . During this time, higher discharge in the northern Adriatic rivers was also observed with a higher contribution originating from the Isonzo/Soča. This data point falls on the mixing line with $-8.6 \%$ as the riverine end-member (Isonzo/Soča) (Fig. 5). Based on the data, it was estimated (Eqs. 6 and 7) that about $10 \%$ of DIC was of freshwater origin. Although this line also approximates other $\delta^{13} \mathrm{C}_{\mathrm{DIC}, \mathrm{GOT}}$ values quite closely, suggesting simple mixing, some of the data fell above the line and were on average by $0.5 \%$ higher indicating that also other processes might influence the DIC at VIDA station in July 2007. As it was found that outgassing is not relevant in this period, the increase $\delta^{13} \mathrm{C}_{\mathrm{DIC}, \mathrm{GOT}}$ could be explained by phytoplankton uptake.

The contribution of rivers was again observed at the end of sampling period in September 2007. At this time, another drop in $p \mathrm{CO}_{2}$ and $p \mathrm{CO}_{2, \mathrm{NT}}$ was noticed (Fig. 4) together with the increase of river discharges (Fig. 3a). It seems that this river plume did not fully reach the study location since only a small decrease in salinity (36.6) and $p \mathrm{CO}_{2}$ (Table 2) was observed. Mixing of the water masses was further influenced by strong bora wind. The modeling studies suggested that during these periods' only smaller plumes of the Rižana and Dragonja might be present (Malačič and Petelin 2009). Two of our $\delta^{13} \mathrm{C}_{\mathrm{DIC}, \mathrm{GOT}}$ data with salinities 36.6 and 37.2 plot on the 
Fig. 4 a Daily mean discharges of Isonzo/Soča in 2007. b

$\delta^{13} \mathrm{C}_{\text {DIC,GOT with the horizontal }}$ line indicating the average value of $\delta^{13} \mathrm{C}_{\mathrm{DIC}}=0.6 \%$ for global surface seawaters (Kroopnick 1985). c Surface values of $\delta p \mathrm{CO}_{2}$ $\delta p \mathrm{CO}_{2, \mathrm{~T}}$, and $\delta p \mathrm{CO}_{2, \mathrm{NT}}$ from March to October 2007 at the VIDA station in the Gulf of Trieste
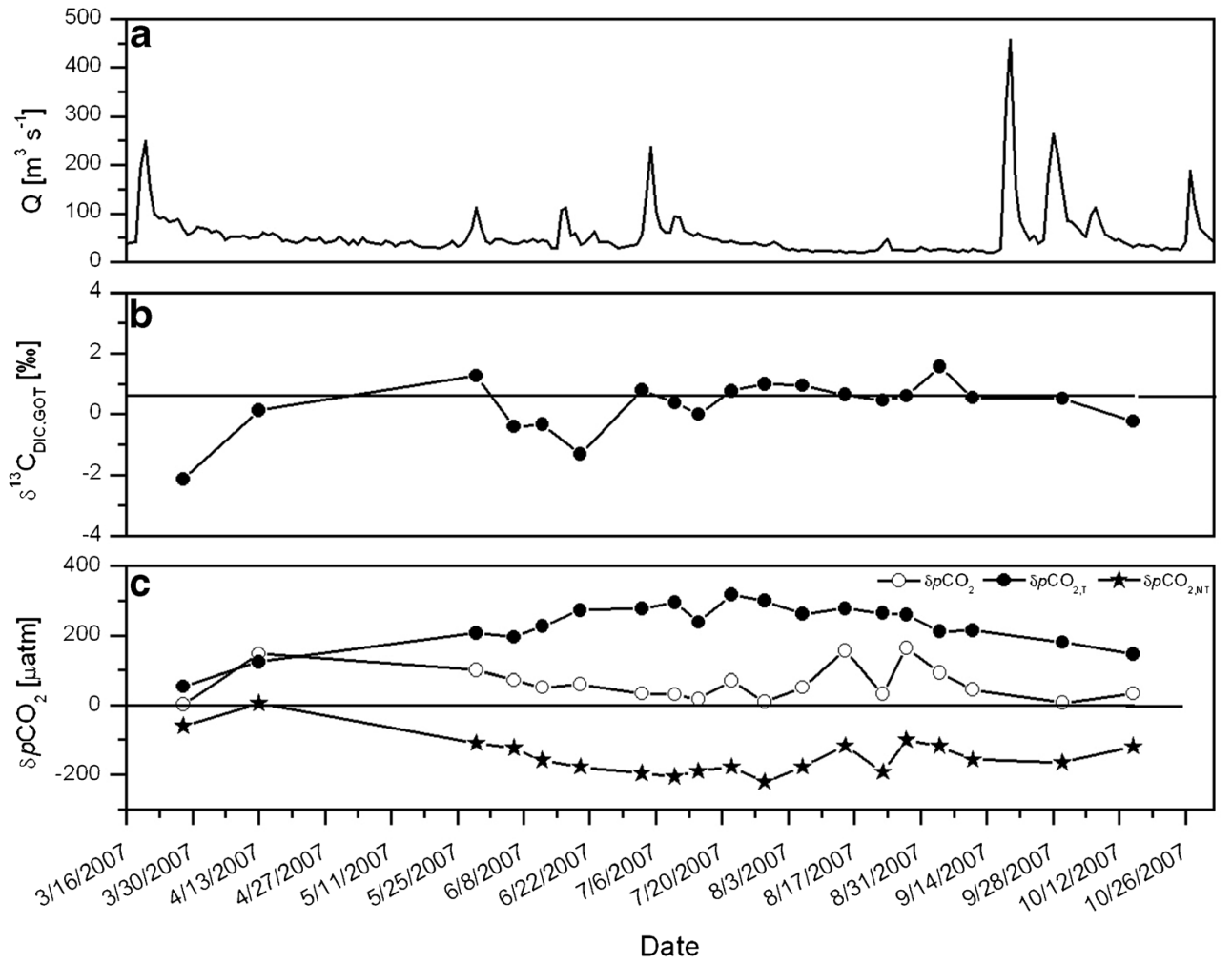

mixing line defined with the end-members from the Isonzo/ Soča River. According to our calculations (Eqs. 6 and 7), riverine input accounted for only $3 \%$ of the DIC. As already observed in May 2007, the highest $\delta^{13} \mathrm{C}_{\mathrm{DIC}, \mathrm{GOT}}$ of $1.6 \%$ were related to phytoplankton uptake, while the lowest $\delta^{13} \mathrm{C}_{\mathrm{DIC}, \mathrm{GOT}}$ value indicated a biogenic $\mathrm{C}$ source. The dynamic of DIC distribution could be also compared with the study performed in the Gulf of Maine, although influenced by low DIC riverine inputs (Salisbury et al. 2009). In their study most of the variability in surface DIC was related to mixing between river water and saline Gulf of Maine waters, however productiverelated uptake was also observed during the spring and early summer. The average biological $\mathrm{CO}_{2}$ uptake of 3.61 and $6.63 \mathrm{mg} \mathrm{C} \mathrm{m}^{-2}$ day $^{-1}$ calculated in 2004 and 2005, respectively, was two orders of magnitude lower comparing to our study. This calculation was performed from dissolved
Fig. 5 The isotopic composition of DIC ( $\left.\delta^{13} \mathrm{C}_{\mathrm{DIC}, \mathrm{GOT}}\right)$ vs. salinity for seawater surface data at VIDA in the Gulf of Trieste during 2007. Estimated conservative mixed distribution calculated from the marine and riverine end-members is indicated by the solid and dotted lines. The freshwater endmembers have a $\delta^{13} \mathrm{C}_{\text {DIC }}$ of -8.6 $\%$ for Isonzo/Soča (solid line) and $-12.2 \%$ for other rivers (dotted line), whereas the marine end-member has a $\delta^{13} \mathrm{C}_{\text {DIC,GOT }}$ value of $0.6 \%$

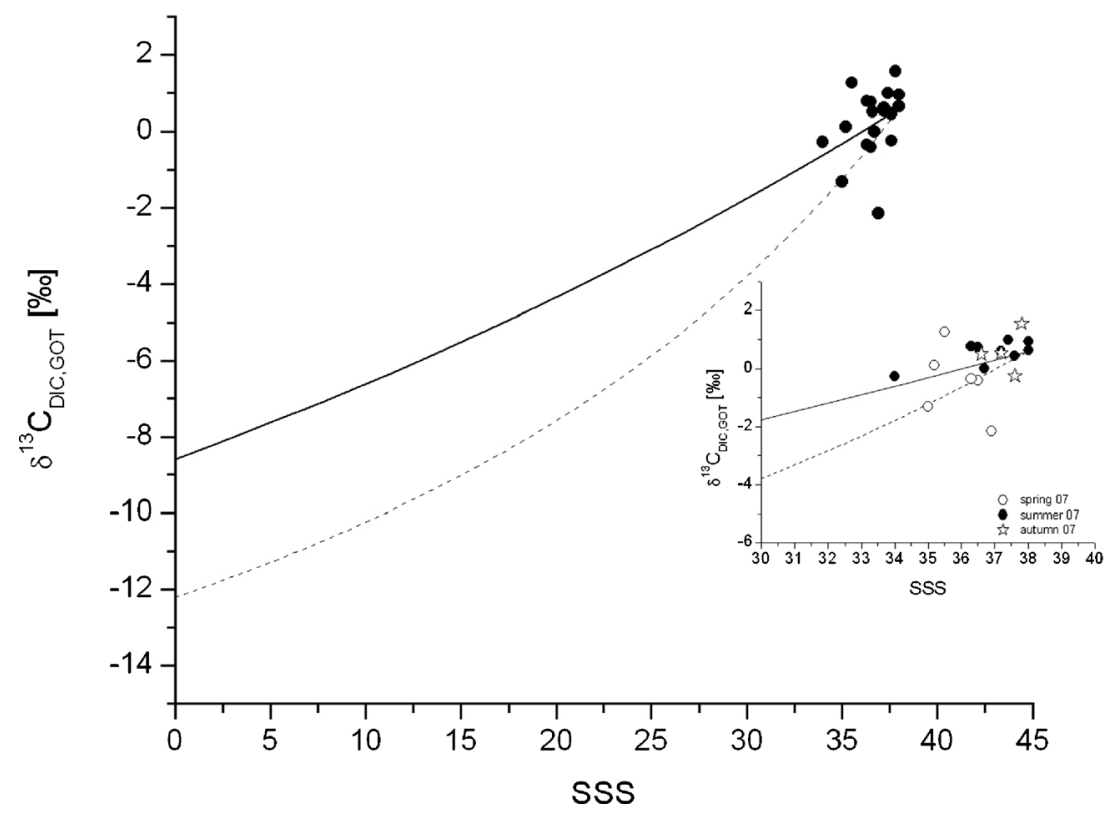


inorganic nitrogen fluxes from Kennebec and Merrimack rivers using C/N Redfield ratio of 6.6:1 (Redfield 1958).

It should also be mentioned that in 2007 , there was a record of low riverine flow, so all these estimates may be on the lower end for river contributions. However, we observed that river plums in spring and autumn lower saturation states of calcite and aragonite (Table 2). These conditions have to be taken into account when ocean acidification is studied, as the most "acidic" carbonate saturation states were observed during higher river flow period.

\section{Conclusions}

This study focused on the influence of riverine input on the inorganic $\mathrm{C}$ system in the Gulf of Trieste where the annual cycle of surface $p \mathrm{CO}_{2}$ was mainly controlled by seasonal variability of seawater $\mathrm{T}$. The advection of continental waters caused direct inputs of high riverine DIC concentrations ranging from 2.96 to $5.12 \mathrm{mmol}^{-1}$ with lower $\delta^{13} \mathrm{C}_{\text {DIC,R }}$ compared with $\delta^{13} \mathrm{C}_{\mathrm{DIC}, \mathrm{GOT}}$. The isotopic composition of DIC in rivers was influenced by carbonate mineral weathering and the addition of biogenic $\mathrm{CO}_{2}$, producing waters with an intermediate $\delta^{13} \mathrm{C}_{\text {DIC,R }}$ of about $-11 \%$. Higher $\delta^{13} \mathrm{C}_{\text {DIC,R }}$ values of about $-8 \%$ were observed in the Isonzo/Soča due to higher contribution of carbonate weathering to DIC. In 2007, the river export ranged from $8.0 \times 10^{8}$ to $6.3 \times 10^{10} \mathrm{~g} \mathrm{C}$ with the lowest observed in the Dragonja and the highest in the Isonzo/Soča, respectively. The highest export of $\mathrm{C}$ from all rivers was observed in October 2007 due to higher discharge. However, the stronger influence of river plumes in seawater at the coastal buoy VIDA was observed only in spring from March to June 2007. This influence coincided with the salinity drop, lower $\mathrm{Ca}$ concentrations, higher $\mathrm{TA}_{\mathrm{GOT}}$ and lower $\delta^{13} \mathrm{C}_{\mathrm{DIC}, \mathrm{GOT}}$ values. In March 2007, the Timavo was probably responsible for the observed changes in the inorganic $\mathrm{C}$ system with a possible smaller contribution from the Dragonja and Rižana, while in July 2007 the influence of the Isonzo/Soča was more pronounced. Based on $\delta^{13} \mathrm{C}_{\text {DIC }}$ values and the isotopic mass balance, it was estimated that rivers represented about $16 \%$ of DIC in spring. The riverine contribution, mainly from the Isonzo/Soča, was less evident in July and autumn 2007 accounting for only 10 and $3 \%$, respectively. In autumn convective mixing and bora wind events could additionally control the riverine contribution to DIC at the seawater surface. In addition, riverine inputs contributed to the decrease in $p \mathrm{CO}_{2}$ due to biological uptake by phytoplankton blooms, promoted by the river nutrient loads. The $\mathrm{CO}_{2}$ uptake estimated from $\delta^{13} \mathrm{C}_{\text {DIC,GOT }}$ was about $45 \pm 10$ and $13 \pm 8 \mu \mathrm{mol} 1^{-1}$ in spring and autumn 2007, respectively. This study indicates that riverine inputs play an important role in the $\mathrm{CO}_{2}$ system in the Gulf of Trieste; however, further investigations are needed to refine the determination of the sources of seawater DIC in the Gulf of
Trieste at more resolved time and space as well as their effect on the biological processing of $\mathrm{C}$.

Our results suggest that the presence of river plumes can cause a decrease in $p \mathrm{CO}_{2}$ even though a high concentration of river DIC is transported to the Gulf of Trieste. This could be related to biological activity associated with an increase in freshwater nutrient input, consistent with some of the previous studies performed in coastal areas (Borges 2005; Salisbury et al. 2009), whereas other studies indicate that estuaries can be a large source of $\mathrm{CO}_{2}$ to the atmosphere (Frankignoulle et al. 1998).

Acknowledgments This research was financially supported by the Slovenian Research Agency under Research Programmes P1-0143, Canada Excellence Research Chair (CERC) in Ocean Science and Technology and LDEO contribution \#7773. Special thanks are given to Corey Lambert for providing laboratory analysis at the University of Michigan. The authors would like to thank Mateja Poje and Mojca Dobnikar Tehovnik from the Slovenian Environmental Agency for providing the river monitoring data. The authors are grateful to the Associate Editor and two anonymous reviewers for their marked interest, constructive comments, and suggestions that improved the manuscript.

\section{References}

Amiotte Suchet, P., J.L. Probst, and W. Ludwig. 2003. Worldwide distribution of continental rock lithology: Implications for the atmospheric/soil $\mathrm{CO}_{2}$ uptake by continental weathering and alkalinity river transport to the oceans. Global Biogeochemical Cycles 17: 10.1029/2002GB001891.

Aldrian, E. et al. 2008. Spatial and seasonal dynamics of riverine carbon fluxes of the Brantas catchment in East Java. Journal of Geophysical Research 113: G03029, doi:10.1029/2007JG000626.

Andersson, A.J., F.T. Mackenzie, and A. Lerman. 2005. Coastal ocean and carbonate systems in the high $\mathrm{CO}_{2}$ world of the Anthropocene. American Journal of Science 305(9): 875-918.

Aucour, A.M., et al. 1999. Use of ${ }^{13} \mathrm{C}$ to trace origin and cycling of inorganic carbon in the Rhône river system. Chemical Geology 159(1): 87-105.

Berner, K.A., and R.A. Berner. 1996. The global water cycle. New Jersey: Prentice-Hall. 397 pp.

Borges, A.V. 2005. Do we have enough pieces of the jigsaw to integrate $\mathrm{CO}_{2}$ fluxes in the coastal ocean? Estuaries 28(1): 3-27.

Borges, A.V., B. Delille, and M. Frankignoulle. 2005. Budgeting sinks and sources of $\mathrm{CO}_{2}$ in the coastal ocean: Diversity of ecosystems counts. Geophysical Research Letters 32(14), L14601.

Borges, A.V., et al. 2006. Carbon dioxide in European coastal water. Estuarine, Coastal and Shelf Science 70: 375-387.

Bouillon, S., R.M. Connolly, and D.P. Gillikin. 2011. Use of stable isotopes to understand food webs and ecosystem functioning in estuaries. Treatise on Estuarine and Coastal Science 7: 143-173. doi:10.1016/B978-0-12-374711-2.00711-7.

Brunet, F., et al. 2005. $\delta^{13} \mathrm{C}$ tracing of dissolved inorganic carbon sources in Patagonian rivers (Argentina). Hydrological Processes 19(17): $3321-3344$.

Cantoni, C., et al. 2012. Carbonate system variability in the Gulf of Trieste (North Adriatic Sea). Estuarine, Coastal and Shelf Science 115: 51-62.

Civita, M., et al. 1995. The Timavo hydrogeologic system: an important reservoir of supplementary water resources to be reclaimed and protected. Acta Carsologica 24: 169-186. 
Chen, C.T., and A.V. Borges. 2009. Reconciling opposite views on carbon cycling in the coastal ocean: Continental shelves as sinks and near-shore ecosystems as sources of atmospheric $\mathrm{CO}_{2}$. DeepSea Research Part II 56: 578-590.

Cozzi, S., et al. 2012. Recent evolution of river discharges in the Gulf of Trieste and their potential response to climate changes and anthropogenic pressure. Estuarine, Coastal and Shelf Science 115: 14-24. doi:10.1016/j.ecss.2012.03.005.

Cozzi, S., et al. 2004. Dynamics of the oceanographic properties during mucilage appearance in the northern Adriatic Sea: analysis of the 1997 event in comparison to earlier events. Journal of Marine Systems 50: 223-241.

DeGrandpre, M.D., et al. 2002. Air-sea $\mathrm{CO}_{2}$ fluxes on the US Middle Atlantic Bight. Deep Sea Research Part II: Topical Studies in Oceanography 49: 4355-4367.

De Vittor, C., A. Paoli, and S. Fonda Umani. 2008. Dissolved organic carbon variability in a shallow coastal marine system (Gulf of Trieste, northern Adriatic Sea). Estuarine, Coastal and Shelf Science 78: 280-290.

Dickson, A.G. 1990a. Standard potential of the reaction $\mathrm{AgCl}(\mathrm{s})+$ $.5 \mathrm{H} 2(\mathrm{~g})=\mathrm{Ag}(\mathrm{s})+\mathrm{HCl}(\mathrm{aq})$ and the standard acidity constant of the ion HSO4- in synthetic sea water from 273.15 to 318.15 K. Journal of Chemical Thermodynamics 22: 113-127.

Dickson, A.G. 1990b. Thermodynamics of the dissociation of boric acid in synthetic seawater from 273.15 to 318.15 K. Deep Sea Research Part A Oceanographic Research Papers 37: 755-766.

Faganeli, J., et al. 2009. Carbon and nitrogen isotope composition of particulate organic matter in relation to mucilage formation in the northern Adriatic Sea. Marine Chemistry 114: 102-109.

Frankignoulle, M., et al. 1998. Carbon dioxide emission from European estuaries. Science 282(5388): 434-436.

Fonda Umani, S., et al. 2007. Major interannual variations in microbial dynamics in the Gulf of Trieste (northern Adriatic Sea) and their ecosystem implications. Aquatic Microbial Ecology 46: 163-175.

Grosbois, C., et al. 2000. Dissolved load of the Loire River: chemical and isotopic characterization. Chemical Geology 170: 179-201.

Gillikin, D.P., et al. 2006. Stable carbon isotopic composition of Mytilus edulis shells: relation to metabolism and $\delta^{13} \mathrm{C}$ of DIC and phytoplankton. Organic Geochemistry 37: 1371-1382.

Hélie, J.F., C. Hillaire-Marcel, and B. Rondeau. 2002. Seasonal changes in the sources and fluxes of dissolved inorganic carbon through the St. Lawrence River-isotopic and chemical constraint. Chemical Geology 186(1): 117-138.

Hellings, L., et al. 1999. Origin and fate of organic carbon in the freshwater part of the Scheldt Estuary as traced by stable carbon isotope composition. Biogeochemistry 47: 167-186.

Hernándes-Ayon, M.J., et al. 2007. Estimating the contribution of organic bases from microalgae to the titration alkalinity in coastal seawaters. Limnology and Oceanography: Methods 5: 225-232.

Hrvatin, M. 1998. Discharge regimes in Slovenia. Geografski zbornik XXXVIII: 60-87.

Kanduč, T., D. Kocman, and N. Ogrinc. 2008. Hydrogeochemical and stable isotope characteristics of the River Idrijca (Slovenia), the boundary watershed between the Adriatic and Black Seas. Aquatic Geochemistry 14(3): 239-262.

Kempe, S. 1982. Long-term records of $\mathrm{CO}_{2}$ pressure fluctuations in fresh waters. In Transport of carbon and minerals in major world rivers, ed. E.T. Degens, 91-323. SCOPE-UNEP: Hamburg.

Kroopnick, P. 1974. Correlations between ${ }^{13} \mathrm{C}$ and $\Sigma \mathrm{CO}_{2}$ in surface waters and atmospheric $\mathrm{CO}_{2}$. Earth and Planetary Science Letters 22(4): 397-403.

Kroopnick, P.M. 1985. The distribution of ${ }^{13} \mathrm{C}$ of $\Sigma \mathrm{CO}_{2}$ in the world oceans. Deep-Sea Research Part A 32: 57-84.

Laruelle, G.G., et al. 2010. Evaluation of sinks and sources of $\mathrm{CO}_{2}$ in the global coastal ocean using a spatially-explicit typology of estuaries and continental shelves. Geophysical Research Letters 37(15).
Longinelli, A., and J.M. Edmond. 1983. Isotope geochemistry of the Amazon basin: a reconnaissance. Journal of Geophysical Research 88: 3703-3717.

Lueker, T.J., A.G. Dickson, and C.D. Keeling. 2000. Ocean $\mathrm{pCO}_{2}$ calculated from dissolved inorganic carbon, alkalinity, and equations for $\mathrm{K}_{1}$ and $\mathrm{K}_{2}$-Validation based on laboratory measurements of $\mathrm{CO}_{2}$ in gas and seawater at equilibrium. Marine Chemistry 70: 105-119.

Malačič, V., and B. Petelin. 2001. Gulf of Trieste. In Physical Oceanography of the Adriatic Sea: Past, Present and Future, ed. B. Cushman-Roisin, M. Gačić, P.-M. Poulain, and A. Artegiani, 167-177. Dordrecht, Netherlands: Kluwer Acad.

Malačič, V., and B. Petelin. 2009. Climatic circulation in the Gulf of Trieste (northern Adriatic). Journal of Geophysical Research 114(C7), C07002.

McElligott, S., et al. 1998. Discrete water column measurements of $\mathrm{CO}_{2}$ fugacity and $\mathrm{pH}_{\mathrm{T}}$ in seawater: A comparison of direct measurements and thermodynamic calculations. Marine Chemistry 60: 63-73.

Meybeck, M. 1982. Carbon, nitrogen, and phosphorus transport by world rivers. American Journal of Science 282(4): 401-450.

Meybeck, M. 1993. C, N, P and S in rivers: from sources to global inputs. In: Interactions of C, N, P and S Biogeochemical cycles and global change, 163-193. Berlin: Springer.

Millero, F.J., et al. 1993. Titration alkalinity of seawater. Marine Chemistry 44: 153-165.

Mucci, A. 1983. The solubility of calcite and aragonite in seawater at various salinity, temperatures, and one atmospheric total pressure. American Journal of Science 283: 780-799.

Moratti, J., and J.L. Probst. 2003. Silicate rock weathering and atmospheric/soil $\mathrm{CO}_{2}$ uptake in the Amazon basin estimated from the river water geochemistry: seasonal and spatial variations. Chemical Geology 197: 177-196.

Ogrinc, N., et al. 2008. Sources and transport of carbon and nitrogen in the River Sava watershed, a major tributary of the River Danube. Applied Geochemistry 23: 3685-3698.

Opsahl, S., R. Benner, and R. Amon. 1999. Major flux of terrigenous dissolved organic matter through the Arctic Ocean. Limnology and Oceanography 44: 2017-2023.

Parkhurst, D.L., and C.A.J. Appelo. 1999. User's guide to PHREEQC (version 2) - a computer program for speciation, batch - reaction, one - dimensional transport, and inverse geochemical calculations. Water-Resources Investigations Report 99-4259.

Pleničar, M., B. Ogorelec, and M. Novak. 2009. The Geology of Slovenia. Ljubljana: Geološki zavod Slovenije. 612 pp.

Redfield, A.C. 1958. The biological control of chemical factors in the environment. American Scientist 46: 205-221.

Robbins, L.L., et al. 2010. CO2calc - a user-friendly seawater carbon calculator for Windows, Max OS X, and iOS (iPhone): U.S. Geological Survey Open-File Report 2010-1280, 17 pp.

Salisbury, J., et al. 2009. Episodic riverine influence on surface DIC in the coastal Gulf of Maine. Estuarine, Coastal and Shelf Science 82: 108-118.

Salisbury, J., et al. 2008. Coastal acidification by rivers: A new threat to shellfish? EOS Transactions AGU 89(50): 513-528.

Sarmiento, J.L., and E.T. Sundquist. 1992. Revised budget for the oceanic uptake of anthropogenic carbon dioxide. Nature 356(6370): 589-593.

Sempéré, R., et al. 2000. Carbon inputs of the Rhone River to the Mediterranean Sea: biogeochemical implications. Global Biogeochemical Cycles 14(2): 669-681.

Smith, S.V., and J.T. Hollibaugh. 1993. Coastal metabolism and the oceanic organic carbon balance. Reviews of Geophysics 31(1): 75-89.

Solidoro, C., et al. 2009. Current state, scales of variability, and trends of biogeochemical properties in the northern Adriatic Sea. Journal of Geophysical Research 114, C07S91. doi:10.1029/2008JC004838.

Spiker, E.C., and L.E. Schemel. 1979. Distribution and stable-isotope composition of carbon in San Francisco Bay. In San Francisco Bay: The urbanized estuary, ed. T.J. Conomos, 195-212. San Francisco: American Association of Advance Science. 
Szramek, K., et al. 2011. Dolomite versus calcite weathering in hydrogeochemically diverse watersheds established on bedded carbonates (Sava and Soča rivers, Slovenia). Aquatic Geochemistry 17: 357-396.

Szramek, K., et al. 2007. Relative weathering intensity of calcite versus dolomite in carbonate-bearing temperate zone watersheds: Carbonate geochemistry and fluxes from catchments within the St. Lawrence and Danube river basins. Geochemistry, Geophysics, Geosystems 8, Q04002. doi:10.1029/2006GC001337.

Takahashi, T., et al. 2002. Global sea-air $\mathrm{CO}_{2}$ flux based on climatological surface ocean $p \mathrm{CO}_{2}$, and seasonal biological and temperature effects. Deep-Sea Research II 49: 1601-1622.

Tamše, S., et al. 2014. Stable isotopes as a tool for nitrogen source identification and cycling in the Gulf of Trieste (Northern Adriatic). Continental Shelf Research, in press.
Telmer, K., and J. Veizer. 1999. Carbon fluxes, pCO2 and substrate weathering in a large northern river basin, Canada: carbon isotope perspectives. Chemical Geology 159(1): 61-86.

Turk, D., J.W. Book, and W.R. McGillis. 2013. $p \mathrm{CO}_{2}$ and $\mathrm{CO}_{2}$ exchange during high bora winds in the Northern Adriatic. Journal of Marine Systems 117-118: 65-71. doi:10.1016/j.jmarsys.2013.02.010.

Turk, D., et al. 2010. Carbon dioxide variability and air-sea fluxes in the northern Adriatic Sea. Journal of Geophysical Research 115, C10043.

$\mathrm{Wu}, \mathrm{Y}$., et al. 2007. Sources and distribution of carbon within the Yangtze River system. Estuarine, Coastal and Shelf Science 71(1): 13-25.

Yang, C., K. Telmer, and J. Veizer. 1996. Chemical dynamics of the St. Lawrence riverine system: $\delta \mathrm{D}_{\mathrm{H} 2 \mathrm{O}}, \delta^{18} \mathrm{O}_{\mathrm{H} 2 \mathrm{O}}, \delta{ }^{13} \mathrm{C}_{\mathrm{DIC}}, \delta^{34} \mathrm{~S}_{\text {sulfate }}$, and dissolved ${ }^{87} \mathrm{Sr} /{ }^{86} \mathrm{Sr}$. Geochimica et Cosmochimica Acta 60 : 851-866. 